\title{
RADIOSCAPHOLUNATE (RSL) FUSION ON SECONDARY OA WRIST WITH NEGLECTED DISLOCATION RADIOCARPAL JOINT AND CONTRACTURE DUE TO ENTRAPMENT OF SUPERFICIAL FLEXOR TENDON INDEX FINGER OF LEFT HAND
}

\author{
Rahmad Rian', Seti Aji Hadinoto², Tito Sumarwoto², Pamudji Utomo \\ ${ }^{1}$ Resident of Orthopaedic \& Traumatology Faculty of Medicine Sebelas Maret University \\ ${ }^{2}$ Consultant of Orthopaedic \& Traumatology Faculty of Medicine Sebelas Maret University - \\ Orthopaedic Hospital Prof. Dr. R. Soeharso Surakarta \\ e-mail: mqatharrft@gmail.com
}

\begin{abstract}
Background: When pain, deformity and instability compromise wrist function, wrist stabilization by means of fusion is a procedure of recognized validity. The goal of wrist arthrodesis is to provide the patient with a stable wrist for power grip and the predictable relief of pain while sacrificing wrist motion. The radioscapholunate (RSL) fusion is one of salvage procedure indicated in the case of traumatic or degenerative osteoarthritis of the radiocarpal joint, involving the lunate facet of the radius. RSL-fusion reduced total wrist motion (3 MC/Rad) in the $\mathrm{F} / \mathrm{E}$ axis to an average of $49 \%$ of $F / E$ in the unfused wrist but preserves midcarpal joint motion while alleviating pain.
\end{abstract}

Case Report: We report a 43-year-old male patient with pain on his left wrist. 10 months before admission, he felt down from stairs with his left hand bear his body weight. He broke his wrist and got surgery at that time. Because still feel pain and his index finger can't fully extensed, he brought to Soeharso orthopaedic hospital. Here, we have done RSL-fusion using cross pinning K-Wire to reduce pain, distal scapoid excision to optimizing radial angulation and release superficial flexor tendon index finger of left hand.

Discussion: With Secondary OA of left wrist post traumatic with neglected radiocarpal dislocation and superficial flexor tendon contracture due to entrapment index finger of left hand post RSL-fusion, distal scapoid excision and release contracture can reduce pain at radiocarpal joint and improve range of movement.

Conclusion: The goal of Radioscapholunate (RSL) fusion is to optimizing wrist motion and strength while minimizing or eliminating pain

Keywords: Radioscapholunate fusion, partial wrist arthrodesis, limited wrist fusion, reduce pain

\section{ABSTRAK}

Latar belakang: Rasa nyeri, deformitas, dan ketidakstabilan mengganggu fungsi dari pergelangan tangan. Stabilisasi pergelangan tangan dengan fusi merupakan prosedur dengan validitas yang diakui. Tujuan dari arthrodesis pergelangan tangan adalah untuk memberikan pasien pergelangan tangan yang stabil untuk cengkeraman yang kuat dan menghilangkan rasa sakit yang dapat diprediksi sambil mengorbankan gerakan pergelangan tangan. Fusi radioskafolunat (RSL) adalah salah satu prosedur penyelamatan yang diindikasikan pada kasus osteoartritis traumatis atau degeneratif sendi radiokarpal, yang melibatkan sisi radius bulan sabit. Fusi RSL mengurangi gerakan pergelangan tangan total (3 MC / Rad) di sumbu F / E menjadi rata-rata 49\% dari F / E di pergelangan tangan yang tidak difusi tetapi mempertahankan gerakan sendi midcarpal sambil mengurangi rasa sakit. Laporan Kasus: Kami melaporkan seorang pasien pria berusia 43 tahun dengan nyeri di pergelangan tangan kirinya. 10 bulan sebelum masuk, ia meraba dari tangga dengan tangan kiri menahan beban tubuhnya. Dia mematahkan pergelangan tangannya dan menjalani operasi saat itu. Karena masih merasakan sakit dan jari telunjuknya belum bisa sepenuhnya diulurkan, ia dibawa ke RS Ortopedi Soeharso. Di sini telah dilakukan RSLfusion menggunakan cross pinning K-Wire untuk mengurangi nyeri, eksisi skapoid distal untuk mengoptimalkan angulasi radial dan melepaskan jari telunjuk tendon fleksor superfisial tangan kiri. 
Diskusi: Dengan OA sekunder pasca trauma pergelangan tangan kiri dengan dislokasi radiokarpal terabaikan dan kontraktur tendon fleksor superfisial akibat jebakan jari telunjuk tangan kiri pasca fusi RSL, eksisi skapoid distal dan kontraktur pelepasan dapat mengurangi nyeri pada sendi radiokarpal dan meningkatkan jangkauan gerakan.

Kesimpulan: Tujuan dari fusi Radioscapholunate (RSL) adalah untuk mengoptimalkan gerakan dan kekuatan pergelangan tangan sekaligus meminimalkan atau menghilangkan rasa sakit.

Kata kunci: Fusi radioskafolunat, artrodesis pergelangan tangan parsial, fusi pergelangan tangan terbatas, mengurangi nyeri

\section{INTRODUCTION}

Patient with isolated radiocarpal joint pain due to noninflammatory degeneration, post-traumatic arthritis, certain carpal instabilities and inflammatory conditions such as rheumatoid arthritis and then make deformity and instability compromise wrist function, wrist stabilization by means of fusion is a procedure of recognized validity. The goal of wrist arthrodesis is to provide the patient with a stable wrist for power grip and the predictable relief of pain while sacrificing wrist motion.

The radioscapholunate (RSL) fusion is one of salvage procedure indicated in the case of traumatic or degenerative osteoarthritis of the radiocarpal joint, involving the lunate facet of the radius. RSL-fusion reduced total wrist motion (3 MC/Rad) in the F-E (flexionextension) axis to an average of $49 \%$ of $F-E$ in the unfused wrist but preserves midcarpal joint motion while alleviating pain.
Many studies have reviewed the medium-term outcomes of RSL fusion with varying results. Although clinical outcome was often good, there are variable reported incidences of nonunion between 0 and $25 \%$.

We report one case of radioscapholunate (RSL) fusion.

\section{CASE PRESENTATION}

Patient complaint about pain on his left wrist. 10 months before admission, patient fell down from stairs with his left hand bear his body weight.

After the incident patient felt pain on his left wrist. By family patient was brought to Prof. DR. R. Soeharso Orthopaedic Hospital Surakarta and had surgery for distal radius. After operation patient still felt pain on his wrist and can not extend his $2^{\text {nd }}$ finger.

Patient has suggested to do a reoperation but refuse due to finance problems.

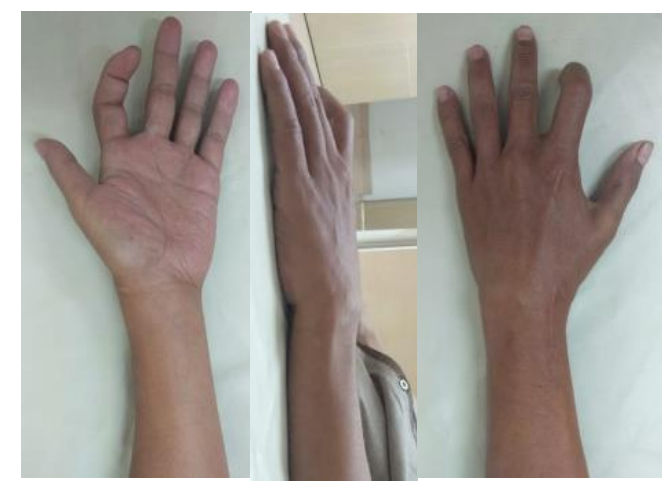

Figure 1. Physical examination of the patient. Source: Personal documentation 
In the physical examination of the left hand, we found prominent of lunate, flexion contracture of $2^{\text {nd }}$ finger, tenderness on peri lunate region and limited range of motion of the wrist

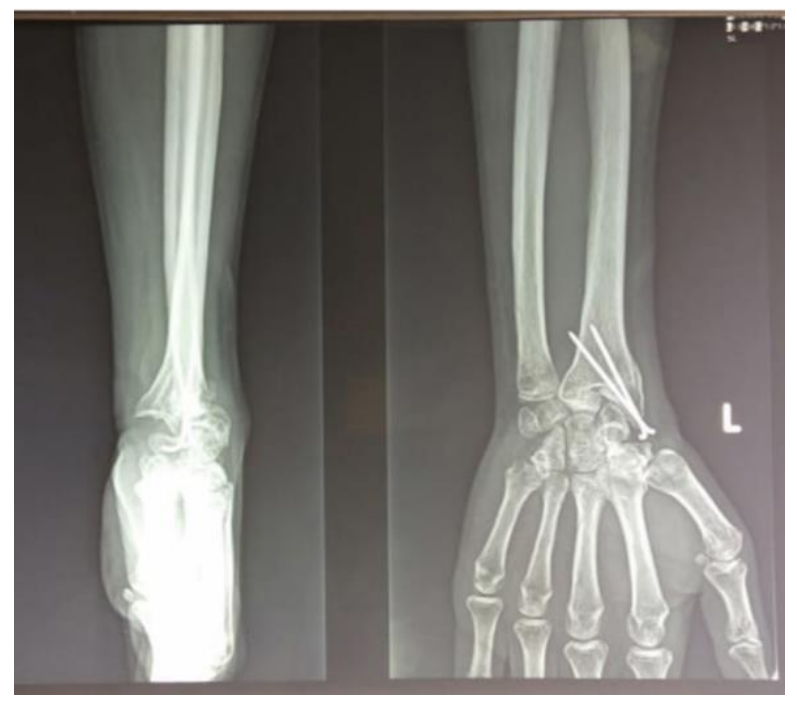

Figure 2. Radiography examination of the patient Source: Personal documentation

From the radiography examination of the wrist showed a secondary osteoarthritis of the wrist especially around the scaphoid. Patient we diagnosed with secondary osteoarthritis of the wrist due to trauma and then we perform radioscapolunate arthrodesis, proximal scaphoid and lunate excision, and release contracture of the $2^{\text {nd }}$ finger flexor tendon.

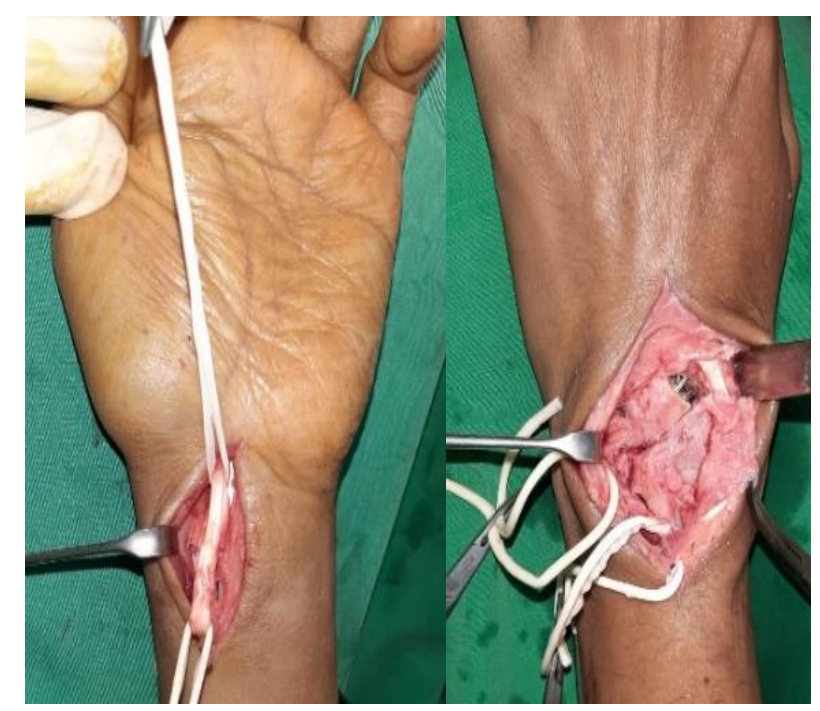

Figure 3. Durante Operation.

Source: Personal documentation 


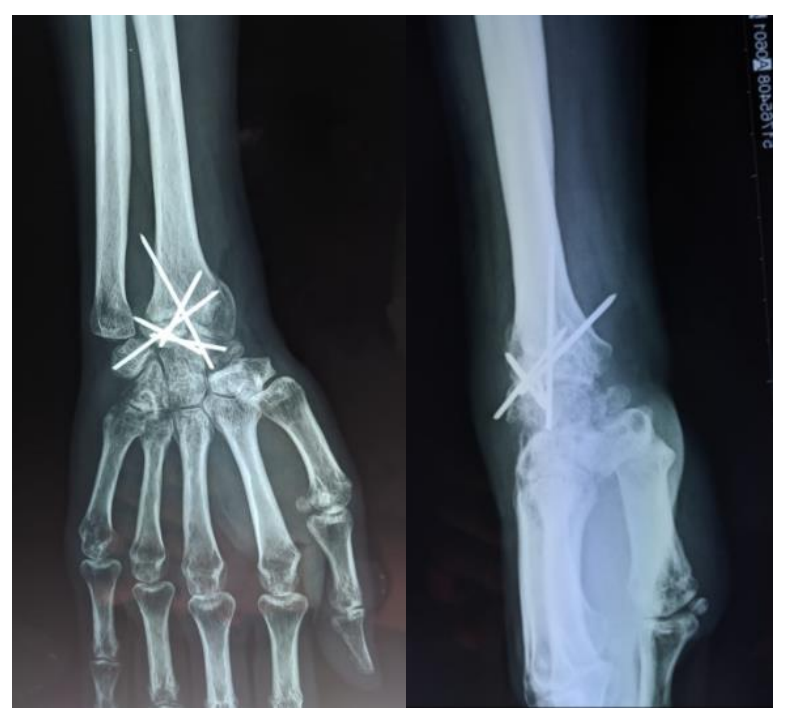

Figure 4. Radiography exam post Operation Source: Personal documentation

\section{DISCUSSION}

An RSL arthrodesis is a clinically effective, pain relieving procedure for patients with isolated, radiocarpal arthritis and can preserve a substantial amount of ROM in an otherwise healthy midcarpal joint. Because RSL arthrodesis can decrease F-E ROM as much as $66 \%$. An absolute prerequisite for this procedure is a functional midcarpal joint, where painless motion will occur following fusion of the diseased radiocarpal joint.

Excision of the distal scaphoid and triquetrectomy have been recommended to unlock the midcarpal joint and increase ROM. But in this case, we perform osteotomy of proximal scaphoid and lunate, also distal radius to increase the stability of arthrodesis. We also performed flexor contracture release of the $2^{\text {nd }}$ finger.

The clinical evaluation for this patient, which include pain and range of motion were done after 2 weeks follow-up. Patient felt no pain when moving his wrist and the range of motion of the wrist was better than before. Patient was able to perform all of the hands function normally, such as grasping.

In this patient, we perform pain relieving procedure of the wrist with radioscapholunate fusion and flexor contracture release of $2^{\text {nd }}$ finger.

\section{REFERENCES}

1. Murray PM. Radioscapholunate Arthrodesis. 2005;21:561-6.

2. Kilgus M, Weishaupt D, Meyer VE. Erfahrungen mit der radiokarpalen Teilarthrodese nach Gordon und King im Langzeitverlauf. 2003;

3. Berkhout MJ, Shaw MN, Berglund LJ, An KN, Berger RA, Ritt MJPF, et al. The Effect Of Radioscapholunate Fusion On Wrist Movement And The Subsequent Effects Of Distal Schaphoidectomy and Triquetrectomy. J Hand Surg Am. 2010;9:740-5. 
4. Shaw MN, Berkhout MJ, Berglund LJ, Berger RA, An KN, Rit. The Effect of Radioscapholunate Fusion on Wrist Movements and the Subsequent Effect of Distal Scaphoidectomy and Triquetrectomy : A Cadaver Study. Annual Meeting of the Orthopaedic Research Society.

5. Mcguire DT, Sa FCO, Uct MO, Bain GI. Radioscapholunate Fusions. 2012;1(212).

6. Mcnary SM, Heyrani N, Volk I, Szabo RM. The Effect of Radioscapholunate Fusion With. J Hand Surg Am [Internet]. 2018;1-7. Available from: https://doi.org/10.1016/j.jhsa.2018.07.009

7. Bain GI, A FAO, Sood A, Yeo CJ, Surgery FH. RSL Fusion with Excision of Distal Scaphoid and Triquetrum: A Cadaveric Study. 2014;37-41.

8. Gomes A, Júnior P, Fonseca R, Gonçalves P, Freitas AD, Chaves AB. Wrist Arthrodesis With Minimal Fixation Preserving The Carpometacarpal Joints Conclusion. Rev Bras Ortop [Internet]. 2010;45(1):67-71. Available from: $h$ ttp://dx.doi.org/10.1016/S2255-4971(15)30219-6

9. Hayden RJ, Jebson PJL. Wrist Arthrodesis. 2005;21:631-40.

10. Barbieri CH, Mazzer2 N, Elui VMC, Fonseca MCR. Resultados funcionais da artrodese do punho. Acta Ortop Bras. 2002;10(1):17-24.

11. Ha NB, Phadnis J, Maclean SBM, Bain GI. JHS ( E) Radioscapholunate fusion with triquetrum and distal pole of scaphoid. 2017;

12. Houvet P. Hand \& Wrist Intercarpal fusions : indications, treatment options and techniques. $2016 ; 1$. 